results in cancer. Unfortunately, at the present time there is so much difference of opinion on almost every point in the mendelian doctrines that one could scarcely put out any results which would satisfy all the adherents of the different hypotheses.

The production of about a thousand spontaneous cancers in specified strains, and the nonoccurrence among this entire number of any cancer in certain other specified strains, no matter what test is applied to them, demonstrates to every reasonable probability the inheritability of cancer, and when these results are characteristically and systematically obtained in such an immense stock as to furnish over 10,000 necropsies and a living stock of about 11,000 mice, with a steady production of between seventy-five and a hundred cancer patients all the time and almost without exception within proved cancer strains, this reasonable probability is raised to an almost indisputable fact; and whether or not my strains of house mice have behaved in hybrid crosses in accordance with the established canon has no bearing whatever on the behavior of cancer. This question lies in quite another field.

In regard to my use of the terms "dominant" and "recessive" with respect to cancer behavior: It is almost the established conviction today that these terms are descriptive and not dynamic, and they furnish in the description of the behavior of cancer in heredity a graphic and convenient tool. That is probably all they furnish in the exposition of any problem in heredity. They may be discarded for even that service within the next few years.

The chief value in the study of cancer of the use of a partial mendelian background of comparison (although the details may be under dispute) is to show to those most interested how far back in a strain cancer may lie and still be transmitted, and by what sorts of crosses this can be done; and to make it plain that in deciding on the inheritability of human cancer and of the method of elimination of cancer from a family, one cannot take as a criterion of judgment whether or not the immediate parents exhibited cancer.

I do not desire or make a strict mendelian interpretation of my results; indeed, I should deplore such an interpretation. I have used mendelian comparisons (1) to make clear the influence of a more or less remote ancestry on later generations of progeny; (2) to show how cancer, like albinism, has been transmitted in my strains through generation after generation by individuals who did not exhibit it; and (3) to demonstrate how cancer thus transmitted finally leaps into expression in the offspring of a pair neither of whom expresses cancer, but both of whom bear it potentially.

The approximation even to conservative mendelian results is strikingly close for such a characteristic as cancer.

Maud Slye, Chicago.

The Otho S..A. Sprague Memorial Institute.

The Notary Fee in Applications for License Under the Harrison Narcotic Law

To the Editor:-I have just received notice from the collector of internal revenue that my application for a license, under the Harrison Narcotic Law, must be sworn to before a notary before it is sent to him.

It seems to me that we ought to make a strong protest against this very unjust rule. The fee for this service is from twenty-five to fifty cents, depending on the location. Usually it is fifty cents, which is not a very large sum; but in the aggregate it will amount to many thousands of dollars, and for what good? Absolutely none, except for the notary.

We have all complied with the law, and our licenses were duly paid for and issued for the four remaining months of the fiscal year. No notary fees were required for that Every physician in the country entitled to use, prescribe or dispense any drug coming under the law is on record at his respective collector's office. The penalty for violation of the law in any way is very severe; therefore, why this unjust fee?

Henry F. Hoyt, M.D., Long Beach,. Calif.
Kaolin, Clay Eaters and Clay-Containing Streams

To the Editor:-Noting in The Journal of June 12 editorial and other reference to the subject of the adsorption, perhaps by virtue of colloidal states of solution, by kaolin, I write to suggest that, in light of the work on its effect on the intestinal bacteria, investigations of the peculiar physiologic or pathologic state of the "clay eaters," numerous in some localities (North Carolina mountains) would be interesting. Especially would this be interesting in connection with the thought and the slight amount of experimental evidence of the possibility of life without the ingestion or the presence in the intestinal canal of micro-organisms.

Entirely aside from all but its physicochemical bearing is the curious condition of the river waters in many of the Southern streams. Even when practically motionless, they seem to hold in suspension indefinitely the whole or a considerable part of the finely divided clay particles of the soil of the territories which they drain. Much attention has for years been devoted to the fluvial waters and drinking water generally by the Italians, lately especially in connection with the etiology of pellagra. It might be that a study of the questions involved would result in considerable advance in our knowledge of many obscure problems of intestinal metabolism.

Jonathan Wright, M.D., Pleasantville, N. Y.

\section{A "Twilight Sleep" Exhibit}

To the Editor:-We have recently had presented in our city films representing "twilight sleep," accompanied by a lecture by a "German doctor." It purports to be under the auspices of the "Motherhood Educational Society." A committee of the Civic League of Saginaw, after seeing it in Bay City, protested against its presentation here-vainly, however, as the mayor found nothing objectionable in either pictures or lecture, and rebuked the women who objected to the commercial exploitation of maternity.

The lecturer subtly attacked the medical profession throughout. At the close, he invites questions from the audience. A good opportunity to test the reaction of the production is thus afforded. Some of the questions were offensive; on these the lecturer waxed witty, and there was hilarity in a considerable part of the audience. Aside from the question of bad taste, his statements were absolutely untrue. $\mathrm{He}$ claimed that twilight sleep was successful in 90 per cent. of all maternity cases.

What can be done to prevent such mischievous presentations to mixed audiences?

I have read with interest The Journal of May 22 with its reports of scopolamin-morphin treatment. In the light of such reports, a production such as was presented here is misleading and harmful in every way.

Mrs. Elizabeth S. Curtis, The Civic League, Saginaw, Mich.

\section{Possibility of Failure in Prophylactic Typhoid Vaccination}

To the Editor:-The following case is instructive from the standpoint of surgical diagnosis:

Miss X, aged 21 years, a nurse in Hahnemann Hospital, complained of anorexia and malaise for three days, at the end of which time she was suddenly taken with general abdominal pains. There was neither nausea nor vomiting. Her temperature was $102.4 \mathrm{~F}$., pulse 120 and respirations 20 . The white cell count was 12,000 . The next morning, Dec. 27 , 1914 , the temperature was $103 \mathrm{~F}$., the pulse 118 , and pain and tenderness were localized in the right iliac fossa. Inquiry developed the fact that she had previously received immunizing injections of typhoid vaccine in another hospital as follows : Oct. 12, 1914, 500 million; Oct. 22, 1914, 1,000 million; Nov. 2, 1914, 1,000 million. The first dose was administered by the resident physician, the second by the supervising nurse and the third by a nurse in training. No ill effects whatever were experienced from the injections. In view of 